\title{
Scylla serrata Forskal as natural source of glucosamine hydrochloride
}

\author{
Muammar FAWWAZ * (D), Pipin VEMILIA (D), Indah MUTMAINNAH (D), Muzakkir BAITS (D) \\ Department of Pharmaceutical Chemistry, Faculty of Pharmacy, Universitas Muslim Indonesia, Makassar 90231, \\ Indonesia. \\ * Corresponding Author. E-mail: muammar.fawwaz@umi.ac.id (M.F.); Tel. +6285255222464.
}

Received: 02 June 2018 / Revised: 15 August 2018 / Accepted: 16 September 2018

\begin{abstract}
Glucosamine (GlcN) has great application in the food, cosmetic, pharmaceutical, and biomaterial areas; it is typically produced by hydrolysis in the exoskeletons of marine animals, one of the types of mud crab (Scylla serrata Forskal). Mud crab shells contain chitin and chitosan compounds which can be further derivatives for the production of GlcN HCl. The purpose of this study is to isolate and determine the level of GlcN HCl by hydrolysis of chitin and chitosan from mud crab shell. GlcN HCl was characterized by Fourier Transform Infra-Red (FT-IR) spectrophotometry, and its quantity was analyzed by UV-Vis spectrophotometry. Both methods used GlcN $\mathrm{HCl}$ as a standard for comparison and calculation of match factor (MF). The results of this study showed that the samples contain $\mathrm{GlcN} \mathrm{HCl}$ either chitin or chitosan. FT-IR spectrum of chitin sample appears at wave number $1033 \mathrm{~cm}^{-1}, 1532 \mathrm{~cm}^{-1}, 3415 \mathrm{~cm}^{-1}$ whereas for chitosan at $1033 \mathrm{~cm}^{-1}, 1532 \mathrm{~cm}^{-1}, 3356 \mathrm{~cm}^{-1}$. Both sample spectrums showed vibration corresponding to ether (-O-), ethyl $\left(\mathrm{CH}_{2}\right)$ and amine group (NH). The MF value of sample chitin and chitosan is 933 and 974, respectively; it shows that the resulting spectra are identical with the standard. The GlcN HCl level of sample chitin and chitosan was 553 and $993 \mathrm{mg} / \mathrm{g}$, respectively. It can be concluded that the waste of mud crab shell has high potential as a natural source of GlcN HCl.
\end{abstract}

KEYWORDS: Chitin; chitosan; glucosamine $\mathrm{HCl}$; mud crab shell.

\section{INTRODUCTION}

The Scylla serrata Forskal is an edible and economically valuable commodity in South-East Asia. The shell wastes of this seafood are essential sources of manufacturing chitin, a biopolymer that has high commercial potential in various industries [1]. Although the use of chitin has been beneficial in a multitude of industries, it has encountered some obstacles for wide use application due to its insolubility hence causing difficulty for its separation from other materials since it is mainly bound to proteins. For the improvement in the utilization of chitin, it needs to be re-processed by chemical or enzymatic reactions for the production of chitosan $[2,3]$. Chitosan has shown various biological activities such as antimicrobial, antitumor, and immuneenhancing activities [4,5]. However, despite the extensive use of chitosan, it still lacks water soluble characteristics [6,7]. Thus this study aims to convert chitosan and chitin into a more flexible compound glucosamine hydrochloride ( $\mathrm{GlcN} \mathrm{HCl})$, which is absent of this disadvantage.

Both chitin and chitosan are sources of 2-amino,2-deoxy-D-glucose (glucosamine) [8]. GlcN HCl is a product from the degradation of chitin and chitosan, and it is the second most abundant polysaccharide in nature extracted from shrimp, crab, insect, and fungal exoskeletons. Chemical hydrolysis of chitin and chitosan followed by bio converting using enzyme [9-11] is among the methods used for the production of $\mathrm{GlcN} \mathrm{HCl}$ as an excellent application potential in the food, cosmetic, pharmaceutical, and biomaterial areas. Isolation of $\mathrm{GlcN} \mathrm{HCl}$ from Penaeus monodon shell waste was done by chemical hydrolysis [12], thus proving that $\mathrm{GlcN} \mathrm{HCl}$ can be obtained from shelled animals, especially crustaceans.

GlcN is referred to the constitution of glycosaminoglycan chains that are essential ingredients of the articular cartilage [13], it is also a substrate to produce aggrecan and proteoglycan that hydrophilizes cartilage, therefore it has been used in many countries based on the increasing evidence of its effectiveness against osteoarthritis together with chondroitin sulfate [14, 15]. In addition to its chondroprotective action, glucosamine is able to exert anticancer activity, although the mechanism of action is not clearly determined. It

How to cite this article: Fawwaz M, Vemilia P, Mutmainnah P, Baits M. Scylla serrata Forskal as natural source of glucosamine $\mathrm{HCl}$. J Res Pharm. 2019; $23(2): 259-266$. 
was found that GlcN reduced proteasome activity and induced growth arrest and apoptosis in ALVA41 prostate cancer cells. The decrease in proteasome activity occurred prior to apoptosis. The researcher also found that glucosamine specifically downregulated PA28 $\gamma$, one of the proteasome activator. Importantly, the overexpression of PA28 $\gamma$ rescued the proteasome inhibition and apoptosis induced by glucosamine [16].

Based on the description above, there are many benefits of GlcN, so it is necessary to trace for other sources from natural. This research is aimed to isolate and determine the level of $\mathrm{GlcN} \mathrm{HCl}$ by hydrolysis of chitin and chitosan from the waste of mud crab shell. Where it can reduce the waste of crustaceans; furthermore, improving the economic value of this waste for use in the health industry.

\section{RESULTS}

\subsection{FT-IR spectrophotometry determination of GlcN $\mathrm{HCl}$}

Components of crab shells such as proteins, calcium minerals, and pigments were separate from chitin which was then followed by the removal of acetyl chain on chitin to produce chitosan. Both polymers were used as starting material to produce $\mathrm{GlcN} \mathrm{HCl}$ by chemical hydrolysis. The product of $\mathrm{GlcN} \mathrm{HCl}$ was prepared using a potassium bromide $(\mathrm{KBr})$ pellet, its structure was determined by FT-IR spectrophotometry accompanied by comparison with the spectrum of standard reference. Infrared radiation is passed through a sample, some of the IR radiation is absorbed by the sample and some of it is passed through (transmitted). The resulting spectrum represents the molecular absorption and transmission, determining what fraction of the incident radiation is absorbed in a particular energy, creating a molecular fingerprint of the sample. The fingerprint is unique for each compound, no two unique molecular structures produce the same infrared spectrum [17].

Identical FT-IR spectra for sample and standard were observed as in Figure 1, 2, and 3. Table 1 depicts FT-IR spectrum of chitin sample with wave numbers $1033 \mathrm{~cm}^{-1}, 1532 \mathrm{~cm}^{-1}, 3415 \mathrm{~cm}^{-1}$ as well as chitosan with wave numbers $1033 \mathrm{~cm}^{-1}, 1532 \mathrm{~cm}^{-1}, 3356 \mathrm{~cm}^{-1}$. These numbers correspond to the vibrations of ether (-O-), ethyl $\left(\mathrm{CH}_{2}\right)$ and amine group $(\mathrm{NH})$ as depicted in Table 2. Most of compounds can be noted in absorption between $4000 \mathrm{~cm}^{-1}$ and $1400 \mathrm{~cm}^{-1}$, this area known as the principal vibration. In this area, there is fundamental vibrationabsorption uptake derived from the functional groups, which showed the presence of $\mathrm{GlcN} \mathrm{HCl}$ content in the samples [18]. In contrast to the chitosan infrared spectra, the absorption band at the wave number $3448.84 \mathrm{~cm}^{-}$ 1 is the primary $\mathrm{NH}$ vibration followed by sharp absorption bands at wave numbers $2923,22 \mathrm{~cm}^{-1}$ corresponding to vibrations of the $\mathrm{CH}$ alkane range, whereas the sharp absorption bands at wave numbers $2359,98 \mathrm{~cm}^{-1}$ are the result of the $\mathrm{NH}$ stretch vibrations of the amines.

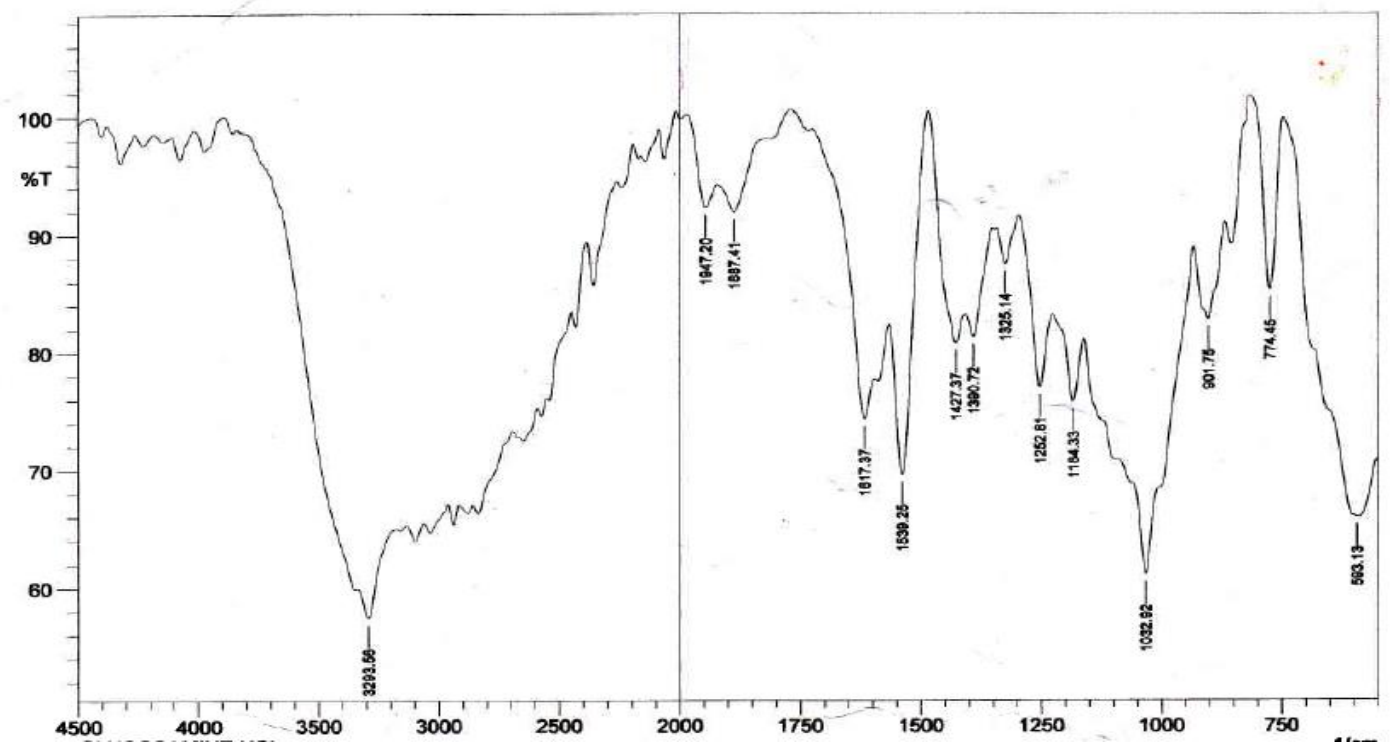

Figure 1. The spectrum of $\mathrm{GlcN} \mathrm{HCl}$ standard by FTIR spectrophotometer. 


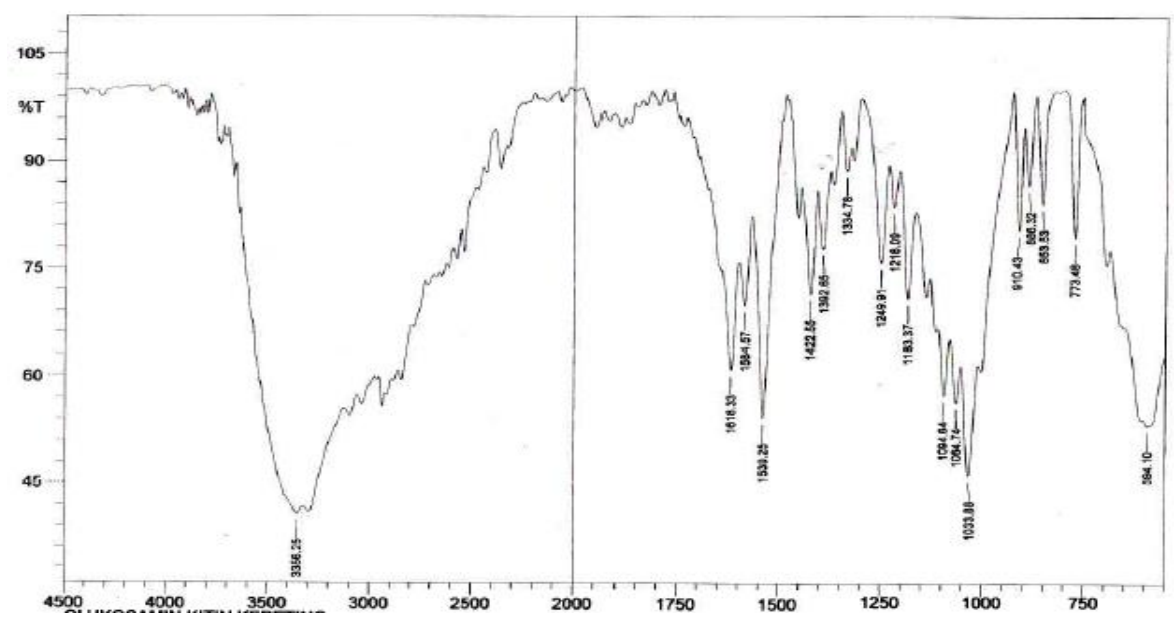

Figure 2. The spectrum of $\mathrm{GlcN} \mathrm{HCl}$ of chitin by FTIR spectrophotometer.

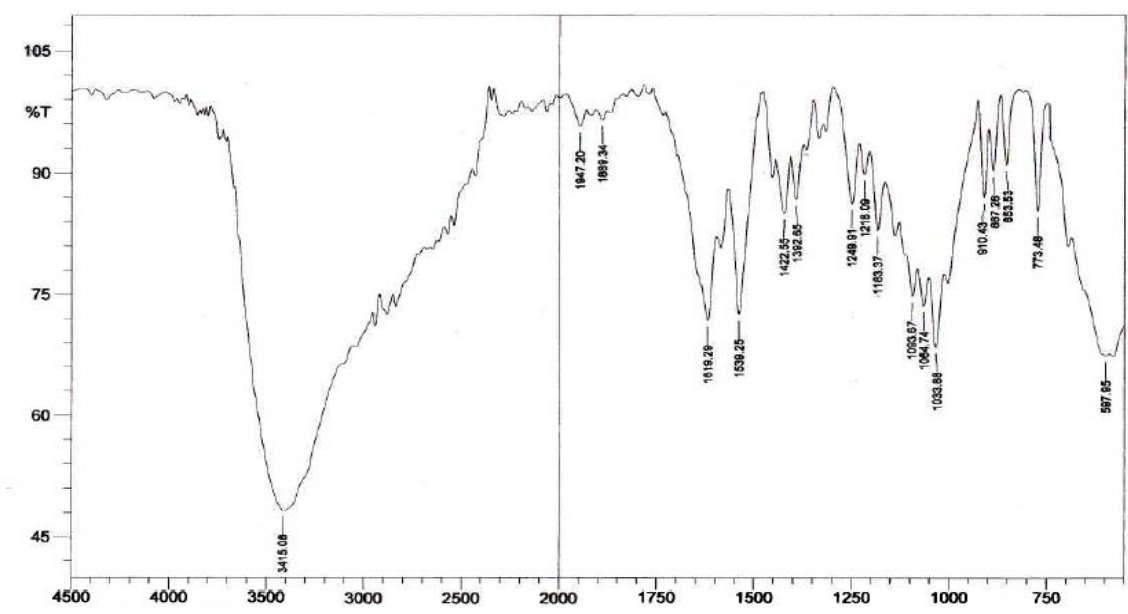

Figure 3. The spectrum of $\mathrm{GlcN} \mathrm{HCl}$ of chitosan by FTIR spectrophotometer.

The comparison of functional groups of $\mathrm{GlcN} \mathrm{HCl}$ standard and product was based on pricing parameters of match factor $(\mathrm{MF})$, this method was used to confirm the characteristic wavenumber between the product and the standard reference. The value of MF is $900-1000$, if the value of MF $\leq 900$ spectra generated is not identical and if MF $\geq 900$ spectra produced is identical. Table 1 and 2 clearly seen that between $\mathrm{GlcN} \mathrm{HCl}$ product and standard has a similarity, which is the MF values of $\mathrm{GlcN} \mathrm{HCl}$ from chitosan is higher than chitin. Based on the data it can be ascertained that the characteristics of $\mathrm{GlcN} \mathrm{HCl}$ produced from chitosan are more similar to the reference than chitin; therefore, it is recommended for the production of GlcN in large quantities by using chitosan sources.

\subsection{UV-Vis spectrophotometry determination of GlcN HCl}

The level of GlcN HCl was determined by UV-Vis spectrophotometry with the standard reference for comparison. It was determined from standard reference that the optimum wavelength for measurement was $512 \mathrm{~nm}$. The standard solutions of $\mathrm{GlcN} \mathrm{HCl}$ were prepared at 50,100, 200, 300, 400 and $500 \mu \mathrm{g} / \mathrm{mL}$, and the standard calibration was obtained by running on UV-Visible spectrophotometer at $512 \mathrm{~nm}$ and then plotting absorbance against concentrations. The best fit of the line curve was calculated by the equation of line $(\mathrm{y}=$ $0,0012 x+0,2683)$, and the linearity was evaluated through the correlation coefficient $\left(R^{2}\right)$. The $R^{2}$ is 0,996 ; it means the correlation between absorbance and concentration is fit because the value is near to one. The sample $100 \mu \mathrm{g} / \mathrm{mL}$ was used for UV-Visible spectrophotometry analysis, to be used as a variable in the equation of line. Based on the quantitative analyses, Table 1 and 2 shows that $\mathrm{GlcN} \mathrm{HCl}$ content from chitosan was higher than chitin. 
Table 1. GlcN HCl of chitin.

\begin{tabular}{ccccccccccc}
\hline \multirow{2}{*}{$\begin{array}{c}\text { Functional } \\
\text { Group }\end{array}$} & \multicolumn{2}{c}{$\begin{array}{c}\text { Wavenumber } \\
\left(\mathbf{c m}^{-\mathbf{1}}\right)\end{array}$} & \multicolumn{3}{c}{ Match Factor Variable } & \multicolumn{3}{c}{ GlcN HCl Determination } \\
\cline { 2 - 9 } & $\mathbf{S t d}^{\mathbf{a}}$ & Chitosan & $\mathbf{X}$ & $\mathbf{Y}$ & $\mathbf{X . Y}$ & $\mathbf{M F}$ & Abs1 $^{\mathbf{b}}$ & Abs2 & Abs3 & $\begin{array}{c}\text { Level } \\
(\mathbf{m g} / \mathbf{g})\end{array}$ \\
\hline$-\mathrm{O}-$ & 1032 & 1033 & 0.120 & 0.165 & 0.019 & 933 & 0.317 & 0.344 & 0.354 & 553 \\
$\mathrm{CH}_{2}$ & 1539 & 1539 & 0.157 & 0.139 & 0.021 & & & & & \\
$\mathrm{NH}_{2}$ & 3293 & 3415 & 0.240 & 0.316 & 0.075 & & & & & \\
\hline
\end{tabular}

In general, the characteristics of $\mathrm{GlcN} \mathrm{HCl}$ from chitosan sources have a higher value compared to GlcN $\mathrm{HCl}$ from the chitin. This is because the purity of $\mathrm{GlcN} \mathrm{HCl}$ from chitosan is better than chitin source. The difference in purity is due to the distinct degrees of deacetylation of chitin and chitosan where the degree of chitosan deacetylation was higher than that of chitin. According to Huskisson, the degree of deacetylation is closely related to the release of acetyl groups from N-acetyl glucosamine to D-glucosamine [19]. The higher the degree of deacetylation, the more acetyl groups of $\mathrm{N}$-acetyl glucosamine are released to form $\mathrm{D}$ glucosamine more and more. A high degree of deacetylation can decrease the acid concentration used for hydrolysis thus simultaneously reducing production costs. Pesek et al. state that high glucosamine purity is more resistant to heat and the product will have a higher melting point [20]. In addition Taşkın et al. state that the compound of low purity contains impurities that will degrade the quality of the product [21].

Table 2. GlcN HCl of chitosan.

\begin{tabular}{ccccccccccc}
\hline \multirow{2}{*}{$\begin{array}{c}\text { Functional } \\
\text { Group }\end{array}$} & \multicolumn{2}{c}{$\begin{array}{c}\text { Wavenumber } \\
\left(\mathbf{c m}^{-1}\right)\end{array}$} & \multicolumn{3}{c}{ Match Factor Variable } & \multicolumn{3}{c}{ GlcN HCl Determination } \\
\cline { 2 - 9 } & $\mathbf{S t d}^{\mathbf{n}}$ & $\mathbf{C h i t i n}$ & $\mathbf{X}$ & $\mathbf{Y}$ & $\mathbf{X . Y}$ & $\mathbf{M F}$ & Abs1 b & Abs2 & Abs3 & $\begin{array}{c}\text { Level } \\
(\mathbf{m g} / \mathbf{g})\end{array}$ \\
\hline$-\mathrm{O}-$ & 1032 & 1033 & 0.120 & 0.336 & 0.040 & 974 & 0.398 & 0.407 & 0.384 & 993 \\
$\mathrm{CH}_{2}$ & 1539 & 1532 & 0.157 & 0.266 & 0.041 & & & & & \\
$\mathrm{NH}_{2}$ & 3293 & 3356 & 0.240 & 0.392 & 0.094 & & & & & \\
\hline
\end{tabular}

a $\mathrm{GlcN} \mathrm{HCl}$ standard

b Absorbance sample in UV-Visible spectrophotometer

\section{DISCUSSION}

Over the years crab meat has become one of the main export commodities of Indonesia. The rise of crab meat consumption simultaneously increases crab shell wastes. Hence it is imperative and lucrative to find ways to convert these shell wastes into useful products. Crab shell typically contains protein $15.60-23.90 \%$, calcium carbonate $53.70-78.40 \%$, and chitin $18.70-32.20 \%$ depending on the crab type and its habitat environment [1]. The chemical reaction of a shell can produce chitin, chitosan, and their oligomers by using concentrated $\mathrm{HCl}$, then purified by column chromatographic fractionation. The method to produce chitin and chitosan known as deproteination, demineralization, depigmentation, and deacetylation [9], can be modified by acetolysis, fluorohydrolysis, and sonolysis [22].

Chitosan as a copolymer of d-glucosamine and N-acetyl-d-glucosamine with $\beta$-(164) linkage, is obtained by alkaline or enzymatic deacetylation of chitin. This material can be used to produce GlcN $\mathrm{HCl}$ by chemical hydrolysis using concentrated $\mathrm{HCl}$ [22]. The hydrolysis process involves two acid-catalyzed hydrolysis reactions, the first is glycosidic linkage (depolymerization), and the other is $N$-acetyl linkage (deacetylation) [9]. This process is favorable because GlcN has been historically prepared by chemical hydrolysis of chitin, using a strong acid, such as a chloric acid $(\mathrm{HCl})$ in the appropriate temperatures [23]. Leite et al. hydrolyzed chitin with $37 \%$ hydrochloric acid $\left(1: 5 \mathrm{~S} / \mathrm{L}\right.$ ratios) by reflux at $100^{\circ} \mathrm{C}$ and different reaction times [24]. Novikov led out the acid hydrolysis of chitin and chitosan with $36.5 \% \mathrm{HCl}$ at 50 and $70{ }^{\circ} \mathrm{C}$ [9] and Mojarrad et al. try to optimize the preparation process of $\mathrm{GlcN} \mathrm{HCl}$ by using some conditions, and the best-fit preparation were 30 and $37 \%$ hydrochloric acid, 9:1 (v/w) acid solution to solid ratio, and $4 \mathrm{~h}$ of reaction time [25]. Fawwaz and colleagues isolated $\mathrm{GlcN} \mathrm{HCl}$ from Penaeus monodon shell, the quantitative analysis showed that the levels of GlcN HCl from chitin and chitosan is 698 and 1,119 mg/g, respectively. Thus, the level in chitosan is higher than in chitin [12].

According to Kralovec and Barrow the number of chitin hydrolysis to glucosamine decreases when the acid concentration used was less than $9 \mathrm{M}$. Low acid levels lead to imperfect hydrolysis and the formation of oligomer chitosan. Incomplete hydrolysis may also be caused by the lack of reaction time even though the 
concentration of acids used reaches $10 \mathrm{M}$ [26]. Therefore, it is vital to optimize the hydrolysis reaction by observing both concentration of acid and reaction time. Besides, the $\mathrm{GlcN} \mathrm{HCl}$ level also influenced by the degree of deacetylation, some studies have shown that GlcN levels from chitosan sources are always greater than chitin sources [12]. This is due to the deacetylation degree of chitosan higher than chitin, based on deacetylation degrees by Domzy and Robbert line method equation.

Some studies demonstrate the potential to produce $N$-Acetyl-d-glucosamine from a-chitin using chitinases of ten marine-derived Aeromonas isolates as a sustainable option to the current chemical process, due to its advantage as a sustainable alternative to the chemical process [27, 28]. This method is useful, but some studies reported that some enzymes produce systemic infections in humans and animals [29]. In opposite, Cardozo et al. found that the isolates of Aeromonas caviae, determined by multilocus sequence analysis (MLSA) using six housekeeping genes, has a high potential for chitinase expression and GlcNAc production. In addition to this, it does not present the virulent genes instead showed hemolytic activity on blood agar [11].

The production of $\mathrm{GlcN} \mathrm{HCl}$ can be conducted via chemical or enzymatic reactions, both methods are advantageous, however at present chemical method is the preferred method for large-scale production. The chemical method by hydrolysis reaction can use chitin and chitosan sources. There are many advantages possessed by chitosan as a raw material in the production of $\mathrm{GlcN} \mathrm{HCl}$, including a higher level of purity than chitin sources. However, the higher production cost of chitosan compare to chitin should be addressed.

\section{CONCLUSION}

The GlcN HCl either on chitin or chitosan has the same wavenumber with standard functional groups of GlcN HCl. Meanwhile the result of MF calculation generated from FT-IR spectra further supported this finding thus concluding that both $\mathrm{GlcN} \mathrm{HCl}$ standard and samples were identical. It was also found that GlcN $\mathrm{HCl}$ level was almost two times higher from chitosan source than chitin. In conclusion, the waste of mud crabs has high potential as sources for production of $\mathrm{GlcN} \mathrm{HCl}$.

\section{MATERIALS AND METHODS}

\subsection{Chemicals and standard solution}

GlcN HCl G8475-25G obtained from Sigma Chemie GmbH Aldrich five grams with a purity of $\geq 99 \%$ over the analysis using UV-Vis spectrophotometry. Pro analysis grade of sodium hydroxide $(\mathrm{NaOH})$, hydrochloric acid $(\mathrm{HCl})$, calcium di-hydroxide $\left(\mathrm{Ca}(\mathrm{OH})_{2}\right)$, iron (II) sulphate $\left(\mathrm{FeSO}_{4}\right)$, acetone, sodium hypochlorite $(\mathrm{NaOCl})$, potassium hydroxide $(\mathrm{KOH})$ and potassium thiocyanate $(\mathrm{KSCN})$ purchased from Merck (Darmstadt, Germany). The mud crab shell KB0985001 collected after identified by Raw Material Division of Bomar Group Company as a seafood exporter in Makassar-Indonesia. The sample was confirmed by Division of Botany, Pharmacognosy and Phytochemistry Laboratory, Faculty of Pharmacy, Universitas Muslim Indonesia. Distilled water was obtained through a Millipore-Q50 Ultrapure water system (Sartorius). The stock solution $(\mathrm{c}=1000 \mu \mathrm{g} / \mathrm{mL}$ ) prepared by dissolving $100 \mathrm{mg}$ of glucosamine standard with $100 \mathrm{~mL}$ of distilled water.

\subsection{Preparation of chitin}

The dried pulverized of sample performed demineralization, the mixture of a gram sample and aqueous $\mathrm{HCl}$ one molar stirred at $25-30^{\circ} \mathrm{C}$ for two hours. The precipitate adjusted of $\mathrm{pH}$ by washing with distilled water until neutral, filtered and dried. The sediment carried out to deproteination by washing with aqueous $\mathrm{NaOH}$ one molar and stirring at $60-70^{\circ} \mathrm{C}$ for one hour. The precipitate separated, adjusted of $\mathrm{pH}$ by washing with distilled water until neutral, filtered and dried. Furthermore depigmentation, the sediment added acetone and stirred with ten milliliters $\mathrm{NaOCl} 0.315 \%$ at room temperature for five minutes. The sediment washed with distilled water until neutral $\mathrm{pH}$, filtered and dried to afford chitin [30].

\subsection{Preparation of chitosan}

The mixture of a gram chitin and aqueous $\mathrm{NaOH} 60 \%$ stirred at $90-100^{\circ} \mathrm{C}$ for one hour. The product is slurry filtered, adjusted of $\mathrm{pH}$ by washing with distilled water and aqueous $\mathrm{HCl}$ one molar until neutral. The slurry washed again with distilled water, filtered and dried to afford chitosan [28]. The product confirmed by FT-IR spectrophotometer using a chitosan standard as comparison [12]. 


\subsection{Glucosamine $\mathrm{HCl}$ on chitin}

The mixture of a gram chitin and aqueous $\mathrm{HCl} 12 \mathrm{M}$ stirred at $68-85^{\circ} \mathrm{C}$ until the hydrolysis complete. The reaction mixture was added distilled water $20 \mathrm{~mL}$ and then filtered with Whatman paper to remove insoluble particles and other impurities. The filtrate added activated charcoal $10 \%$, stirred at $60^{\circ} \mathrm{C}$ for 30 minutes to get a pale-yellow solution. The solution was evaporated over the water bath to get a pale-yellow crystal, washed with ethanol, dried at $50^{\circ} \mathrm{C}$ in an oven to afford $\mathrm{GlcN} \mathrm{HCl}[31,32]$.

\subsection{Glucosamine $\mathrm{HCl}$ on chitosan}

The mixture of a gram chitosan and concentrated $\mathrm{HCl}(20 \mathrm{~mL})$ stirred at $90^{\circ} \mathrm{C}$ for 75 minutes. The resulting brownish black solution was added distilled water $20 \mathrm{ml}$ [14]. The mixture filtered using Whatman filter to remove insoluble particles and other impurities. The filtrate added activated charcoal $10 \%$, stirred at $60^{\circ} \mathrm{C}$ for 30 minutes to get a pale-yellow solution. The solution evaporated over the water bath to get a paleyellow crystal, washed with ethanol, dried at $50^{\circ} \mathrm{C}$ in an oven to afford GlcN $\mathrm{HCl}$ [32].

\subsection{FT-IR spectrophotometry}

The product of GlcN HCl was confirmed by FT-IR over pellets of potassium bromide ( $\mathrm{KBr}$ ) to form a transparent thin layer and then measured at wave range 4000-800 $\mathrm{cm}^{-1}$ [14]. The spectrum compared to GlcN $\mathrm{HCl}$ standard.

\subsection{UV-Vis spectrophotometry}

GlcN HCl standard prepared by series concentration of 50, 100, 200, 300, 400 and $500 \mu \mathrm{g} / \mathrm{mL}$. For three milliliters of each standard and $100 \mu \mathrm{g} / \mathrm{mL}$ sample added acetyl acetone four percent in aqueous sodium carbonate $1.25 \mathrm{~N}$, the mixture was heated at $900^{\circ} \mathrm{C}$ for an hour, cooled to room temperature, add $0.75 \mathrm{~mL}$ of reagent Ehrlich, allowed to stand for 30 minutes. The absorbance was measured at the maximum wavelength $(512.36 \mathrm{~nm})$. The sample was done by three replications [33].

\subsection{Data analysis}

Match factor determined to show the identical between standard and sample regarding the FT-IR analysis, using the equation below:

$$
\mathrm{MF}=\frac{10^{3}\left\{\sum X \cdot Y-\left(\sum X \cdot \Sigma Y\right)\right\}^{2}}{\left\{\sum \mathbf{X}^{2}-\left(\frac{\sum X \cdot \Sigma^{Y} Y}{\mathbf{n}}\right)\right\}\left\{\sum \mathbf{Y}^{2}-\left(\frac{\Sigma \mathrm{Y} \cdot \Sigma \mathrm{YY}}{\mathbf{n}}\right)\right\}}
$$

MF : 900-1000 showed the value of the two spectra are identic

$X \quad$ : Absorbance spectrum of standard

Y : Absorbance spectrum of sample

A calibration standard curve for GlcN obtained by running on UV-Visible spectrophotometer and then plotting absorbance against concentrations. The best fit of the line curve calculated by equation of line. Linearity was evaluated through the correlation coefficient $\left(\mathrm{R}^{2}\right)$. The correlation coefficient, intercept and slope of calibration curve calculated. The best fit of data determined by linear regression using the following equation: $\mathrm{Y}=\mathrm{bx}+\mathrm{a}$ where, $\mathrm{Y}=$ Absorbance, $\mathrm{b}=$ Slope, $\mathrm{x}=$ Concentration and $\mathrm{a}=$ Intercept.

Acknowledgement: The authors acknowledge to Dean of Faculty of Pharmacy and Head of the Laboratory of Pharmaceutical Chemistry Faculty of Pharmacy, Universitas Muslim Indonesia for their support and encouragement in carrying out his college work.

Author contributions: Concept - M.F.; Design - M.F., P.V., I.M.; Supervision - M.F. M.B; Materials - M.F; Data Collection and/or Processing - P.V., I.M.; Analysis and/or Interpretation - M.F., P.V., I.M.; Literature Search - M.F., P.V., I.M.; Writing - M.F., P.V., I.M.; Critical Reviews - M.F., P.V., I.M, M.B.

Conflict of interest statement: The authors declared no conflict of interest. 


\section{REFERENCES}

[1] Ahmed TA, Aljaeid BM. Preparation, characterization, and potential application of chitosan, chitosan derivatives, and chitosan metal nanoparticles in pharmaceutical drug delivery. Drug Des Dev Ther. 2016; 10: 483-507. [CrossRef]

[2] De Queiroz Antonino RSCM, Lia Fook BRP, de Oliveira Lima VA, de Farias Rached RÍ, Lima EPN, da Silva Lima RJ, Peniche Covas CA, Lia Fook, MV. Preparation and characterization of chitosan obtained from shells of shrimp (Litopenaeus vannamei Boone). Mar Drugs. 2017; 15(5): 141. [CrossRef]

[3] Saleh A, Mukhtar SA, Fawwaz M. Deacetylation degree of chitosan by various bases and its metal adsorption ability related on antioxidant activity. J Chem Pharm Res. 2015; 7(11): 265-269.

[4] Mattaveewong T, Wongkrasant P, Chanchai S, Pichyangkura R, Chatsudthipong V, Muanprasat C. Chitosan oligosaccharide suppresses tumor progression in a mouse model of colitis-associated colorectal cancer through ampk activation and suppression of nf-kappa b and mtor signaling. Carbohyd Polym. 2016; 145: 30-36. [CrossRef]

[5] Wang GY, Chen YY, Wang P, Wang YF, Hong H, Li YL, Qian JC, Yuan Y, Yu B, Liu CS. Preferential tumor accumulation and desirable interstitial penetration of poly(lactic-co-glycolic acid) nanoparticles with dual coating of chitosan oligosaccharide and polyethylene glycol-poly(d,1-lactic acid). Acta Biomater. 2016; 29: 248-260. [CrossRef]

[6] Medina SH, Tekumalla V, Chevliakov MV, Shewach DS, Ensminger WD, El-Sayed MEH. N-acetylgalactosaminefunctionalized dendrimers as hepatic cancer cell-targeted carriers. Biomaterials. 2011; 32(17): 4118-4129. [CrossRef]

[7] Fattahi A, Sadrjavadi K, Golozar MA, Varshosaz J, Fathi MH, Mirmohammad-Sadeghi H. Preparation and characterization of oligochitosan-tragacanth nanoparticles as a novel gene carrier. Carbohyd Polym. 2013; 97(2): 277283. [CrossRef]

[8] Synowiecki J, Al-Khateeb NA. Production, properties, and some new applications of chitin and its derivatives. Crit Rev Food Sci Nutr. 2003; 43(2): 145-171. [CrossRef]

[9] Kidibule PE, Santos-Moriano P, Jiménez-Ortega E, Ramírez-Escudero M, Limón MC, Remacha M, Plou FJ, SanzAparicio J, Fernández-Lobato M. Use of chitin and chitosan to produce new dechitooligosaccharides by chitinase Chit42: enzymatic activity and structural basis of protein specificity. Microb Cell Fact. 2018; 17: 47. [CrossRef]

[10] Pichyangkura R, Kudan S, Kuttiyawong K. Quantitative production of 2-acetamido-2-deoxy-D-glucose from crystalline chitin by bacterial chitinase. Carbohydr Res. 2002; 337(6): 557-559. [CrossRef]

[11] Cardozo FA, Gonzalez JM, Feitosa VA. Bioconversion of a-chitin into N-acetyl-glucosamine using chitinases produced by marine-derived Aeromonas caviae isolates. World J Microbiol Biotechnol. 2017; 33: 201. [CrossRef]

[12] Fawwaz M, Baits M, Saleh A, Irsyaq MR, Pratiwi RE. Isolation of glucosamine $\mathrm{HCl}$ from Penaeus monodon. Int Food Res J. 2018; 25(5): 2173-2176.

[13] Reginster J-Y, Neuprez A, Lecart M-P, Sarlet N, Bruyere O. Role of glucosamine in the treatment for osteoarthritis. Rheumatol Int. 2012; 32(10): 2959-2967. [CrossRef]

[14] Sibi G, Dhananjaya K, Ravikumar KR. Preparation of glucosamine hydrochloride from crustacean shell waste and it's quantitation by RP-HPLC. Am-Euras J Sci Res. 2013; 8(2): 63-67.

[15] Ogata T, Ideno Y, Akai M, Seichi A, Hagino H, Iwaya T, Doi T, Yamada K, Chen AZ, Li Y, Hayashi K. Effects of glucosamine in patients with osteoarthritis of the knee: a systematic review and meta-analysis. Clin Rheumatol. 2018: 1-9. [CrossRef]

[16] Liu BQ, Meng X, Li C, Gao YY, Li N, Niu XF, Guan Y, Wang HQ. Glucosamine induces cell death via proteasome inhibition in human ALVA41 prostate cancer cell. Exp Mol Med. 2011; 43(9): 487-493. [CrossRef]

[17] Stuart B. Infrared Spectroscopy: Fundamentals and Applications. John Wiley \& Sons, Ltd. 2004.

[18] Fawwaz M, Vemilia P, Mutmainnah I, Naid T. Production and determination of glucosamine from chitosan of mud crab shell. Asian J Pharm Clin Res. 2018; 11(4): 61.

[19] Huskisson EC. 2008. Glucosamine and chondroitin for osteoarthritis. J Int Med Res. 2008; 36(6): 1-19. [CrossRef]

[20] Pesek J, Matyska M, Jimena A, Juan J, Jo A, Berioso B. Analysis of glucosamine using aquous normal phase chromatography. LWT - Food Sci Technol. 2016; 65(1): 777-782. [CrossRef]

[21] Tasskin P, Casinag H, S,en M. The effect of degree of deacetylation on the radiation induced degradation of chitosan. Radiat Phys Chem. 2014; 94(1): 236-239. [CrossRef]

[22] Shahidi F, Abuzaytoun RB. Chitin, chitosan, and co-products: Chemistry, production, applications, and health effects. Academic Press. 2005; 49: 93-135. [CrossRef] 
[23] Aam BB, Heggset EB, Norberg AL, Sorlie M, Varum KM, Eij-sink VG. Production of chitooligosaccharides and their potential applications in medicine. Mar Drugs. 2010; 8(5): 1482-1517. [CrossRef]

[24] Leite A, Silveira I, Matos V. Optimization of Synthesis, Physical and Chemical Analysis and Use in An Experimental Model of Glucosamine Hydrochloride and Glucosamine, In: VI Northeast Regional Meeting SBBQ. 2002; 4:1-12.

[25] Mojarrad JS, Nemati M, Valizadeh H, Ansarin M, Bourbour S. Preparation of glucosamine from exoskeleton of shrimp and predicting production yield by response surface methodology. J Agric Food Chem. 2007; 55(6): 22462250. [CrossRef]

[26] Marine Neutraceticals and Functional Foods. Kralovec JA, Barrow CJ. (Eds). CRC Press, London, 2008.

[27] Liu Y, Shin HD, Chen R, Li J, Du G, Chen J. Microbial production of glucosamine and N-acetylglucosamine: advances and perspectives. Appl Microbiol Biotechnol. 2013; 97(14): 6149-6158. [CrossRef]

[28] Jung WJ, Park RD. Bioproduction of chitooligosaccharides: present and perspectives. Mar Drugs. 2014; 12(11): 53285356. [CrossRef]

[29] Janda JM, Abbott AL. Evolving concepts regarding the genus Aeromonas: an expanding panorama of species, disease presentation, and unanswered questions. Clin Infect Dis. 1998; 27(2): 332-344. [CrossRef]

[30] Hargono A, Sumantri I. Chitosan production from waste shells of shrimp and its application in reducing cholesterol of goat fat. Reaktor. 2008; 12(1): 53-57.

[31] Benavente M, Arias S, Morena L. Production of glucosamine hydrochloride from Crustacean shell. J Pharm Pharmacol. 2015; 3: 20-26. [CrossRef]

[32] Xavier M. PhD Thesis. Standardization of optimum conditions for the production of glucosamine hydrochloride from chitin. Fish Processing Division, Cochin University of Science and Technology, Cochin, India. 2006.

[33] Sitompul S. Optimal time of hydrolysis of chitin of crickets and termites. Bogor: Livestock Research Institute. Indonesia. 2011

This is an open access article which is publicly available on our journal's website under Institutional Repository at http://dspace.marmara.edu.tr. 